\title{
Dynamic response of monsoon precipitation to mineral dust radiative forcing in the West Africa region
}

\author{
Julius Adekola Akinyoola ${ }^{1}$-V. O. Ajayi ${ }^{2}$ B. J. Abiodun ${ }^{3} \cdot$ K. O. Ogunjobi ${ }^{2} \cdot$ Imoleayo E. Gbode $^{2}$. \\ Stephen Bunmi Ogungbenro
}

Received: 2 April 2019 / Accepted: 23 July 2019 / Published online: 10 August 2019

(C) The Author(s) 2019

\begin{abstract}
Mineral dust over West Africa region modulates summer monsoon through direct radiative forcing. This study examined the impact of mineral dust radiative forcing on West Africa Monsoon variability with the aid of Regional Climate Model (RegCM4) at $50 \mathrm{~km}$ grid resolution driven by ERA Interim re-analysis. Three experiments were performed; first with the non-dust aerosol version of the model (CONTROL), and second with the dust aerosol module (DUST) and with an increase in the dust concentration (DOUBLE DUST). The simulation was run from October, 2004 to December, 2005 over West Africa domain with the first 3 months taken as spin up for model stability. The result shows that there was no significant change with Control and Dust case experiment but as the dust AOD increases from 1.0 to 2.0, radiation flux at the Top of Atmosphere changes from -60 to $-80 \mathrm{~W} / \mathrm{m}^{2}$ in the Double dust experiment. The Surface Long-wave Radiation Flux of $8.0 \mathrm{~W} / \mathrm{m}^{2}$ remains unchanged in both cases. The Outgoing Long-wave Radiation (OLR) flux changes from 2.0 to $4.0 \mathrm{~W} / \mathrm{m}^{2}$ indicating reduction in convective formation and as well as decrease in precipitation of $2 \mathrm{~mm}$ /day in the Sahel, while precipitation increases from 2 to $4 \mathrm{~mm} /$ day in the Guinea coast region. There was also strengthening of TEJ core and weakening of AEJ above average as dust concentration increases in some parts of the region during the monsoon period. The air temperature increases from 22.5 to $38.5^{\circ} \mathrm{C}$ in both cases from coastal area to Sahelian region of West Africa. It was concluded that substantial amount of dust concentration in the atmosphere could trigger and increase radiative forcing of aerosols thereby sensitive to monsoon variability and results in enhancement of precipitation amount in the Guinea coast and reduction of precipitation amount in the Sahel region of West Africa. Meanwhile, there is need to inquire more into difference aerosol concentration per specie that can trigger or increase radiative forcing in the atmosphere.
\end{abstract}

Keywords Radiative forcing $\cdot$ Monsoon $\cdot$ Dynamics $\cdot$ Enhancement

\section{Introduction}

West Africa monsoon is highly variable and its variability has led to incessant increase in flood occurrence in some parts of the region, while other parts had suffered immense drought which endanger crops and animal growth. This

Julius Adekola Akinyoola

omoakinyoola@gmail.com

1 Department of Agriculture and Bioenvironmental Engineering Technology, Rufus Giwa Polytechnic, P.M.B 1019, Owo, Nigeria

2 Department of Meteorology and Climate Science, Federal University of Technology, P.M.B 704, Akure, Nigeria

3 Department of Geographical Science and Environment, University of Cape Town, Cape Town, South Africa challenge of dramatic change in the precipitation regime from wet in the early 1960 s to drier condition in the late 1970s. This also includes changes in other associated rain producing system. For example, African Easterly Jet (AEJ) at $600 \mathrm{hpa}$ pressure level tends to be weaker and more pole ward, while the 200 hpa Tropical Easterly Jet (TEJ) and the monsoonal flow become stronger during the wet season (Fontaine et al. 1995; Sultan and Janicot 2003; Sylla et al. 2012; Grist and Nicholson 2001. More often than not, monsoon variability has been linked to aerosol radiative forcing among other factors. Here, we will focus on the direct radiative forcing of mineral dust impact on the monsoon variability in the region. Although many works have addressed radiative forcing of mineral dust in the West Africa climate system, yet there is need for accurate quantification of aerosol concentration that can initiate forcing. 
Aerosol characteristics with different species and emission in the West Africa region have been widely discussed. Specific inventories of different aerosols including carbonaceous aerosol from biomass burning and mineral dust (Marticorena et al. 2010) have been developed. Aerosol emission pathway, seasonal variation, and transportation with relative to size distribution and model parameterization have also been discussed. For example (Andreae et al. 2005; Diedhiou et al. 1998; Fontaine et al. 1998; Goudie and Middleton 2001; Haywood and Shine 1997; Kaufman et al. 2002; Liao and Seinfeld 1998; Titos et al 2016; Wang and Eltahir 2000; Ming and Ramaswamy 2011; Akinyoola et al. 2018) in their intense discussion have explained different aerosol emission pathway and the seasonal variation in the West Africa region. In particular, Mineral dust ubiquitously found in the tropospheric layer of Atmosphere in the West Africa region and the maximum concentration is found in winter due to Sahara transport, while the daily concentration is extremely high during both dry and wet seasons (Marticorena et al. 2010; Eresanya et al. 2017; Ogunjobi and Awoleye 2019). The deposition pathway through which dust is being washed off from the atmosphere as a result of mesoscale convective activities had also been identified. Physico-chemical properties of mineral dust, and the radiative forcing characteristics which controls or influence precipitation processes have been extensively investigated. Single Scattering Albedo (SSA) is a critical parameter to determine the sign of the aerosol forcing. Levin and Ganor (1996), Miller and Tegen (1998), Haywood and Boucher (2000), Takemura et al. (2005), and Choobari et al. (2014) shows that mineral dust consistently scatter radiation in the visible band of radiation spectrum. They also found that SSA of the submicron dust has been estimated to be $\sim(0.99 \pm 0.01)$ at $0.55 \mu \mathrm{m}$ and $\sim 0.90$ with the addition of the coarse mode. In line with this (Camara et al. 2010; Zakey et al. 2006a, b; Konare et al. 2008a, b; Abiodun et al. 2012; Solmon et al. 2008; Marcella and Eltahir 2014a, b; N'Datchoh et al. 2018) in their different simulation, results have concluded that dust radiative forcing influence precipitation activities in the region and were able to ascertained the forcing characteristics of Dust across the region. Yet, it is not widely agreed that climate feedback is relative to substantial amount of dust present in the atmosphere; certain mineral dust with minimum value of SSA based on seasonal variation present in the atmosphere will have little or no impact on the precipitation processes, while a substantial amount will bring significant change in the rain producing system. Substantial dust concentration will make a substantial impact on the rain producing system and processes. The sensitivity of the model to significant changes in the mineral Dust radiative forcing is essential to quantify the response of precipitation and air temperature in the region.
The objective of this work is to investigate the influence of mineral dust radiative forcing on the monsoon dynamics and the sensitivity of model to changes induced by mineral dust radiative forcing. This paper is divided into four sections; the first section presents the introduction, second session presents the data and method including model configuration and experimental design, the third section present the results and discussion, while the fourth session discuss the Summary and conclusion.

\section{Data and methods}

\section{Study area}

The climate of West Africa region is governed by the North-South movement of the Inter-tropical Discontinuity (ITD). The West Africa domain is divided into three climatic zones according to (Omotosho and Abiodun 2007; Abiodun et al. 2012; Fink et al. 2016): (1) The Sahelian zone, with irregular annual rainfall that does not exceed $500 \mathrm{~mm}$, and a maximum rainfall occurring in August. This zone is located roughly at $12.5^{\circ} \mathrm{N}$ latitude and its climate is semi-arid. (2) The Sudanian zone with a precipitation amount between less than $200 \mathrm{~mm}$ in the north of Nigeria and $1000 \mathrm{~mm}$ in the north of Mali. The climate is sub-humid and located approximately between 9 and $12.5^{\circ} \mathrm{N}$. (3) The tropical humid Guinea Cost zone located along the Gulf of Guinea, characterized by annual mean rainfall higher than $1500 \mathrm{~mm}$, as shown in Fig. 1.

\section{Model configuration}

This study employs the Regional Climate Model version 4 (RegCM4) developed at the International Center for Theoretical Physics (ICTP) due to its wide applications in regional climate and environmental change studies (Giorgi

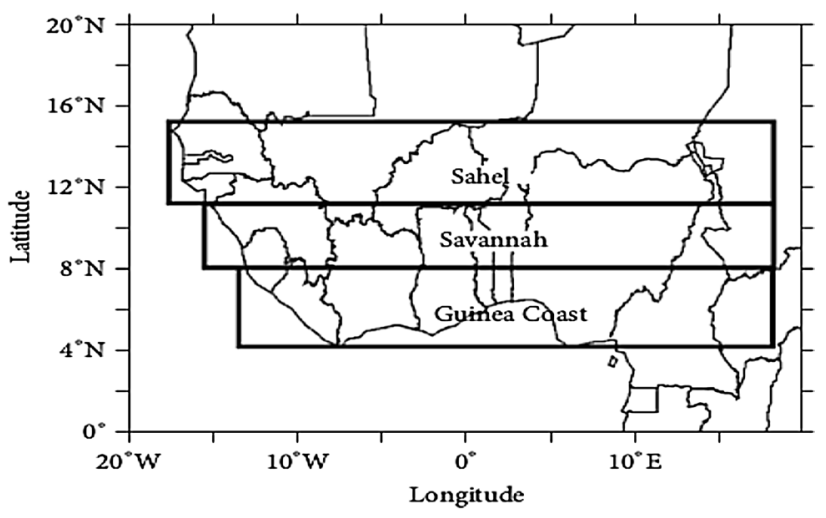

Fig. 1 Subclassification of West Africa into major three climatic zones. (source: Omotosho and Abiodun 2007) 
et al. 2012). The model was configured with grid dimension of $80 \times 120,18 \sigma$ levels and with $50 \mathrm{~km}$ grid horizontal resolution driven by ERA Interim re-analysis. The dust scheme of RegCM4 represents the dry dust particle-size distribution through size bin approach. The whole-size spectrum of dust particles covers a diameter range of $0.01-20.0 \mathrm{~m}$, divided into four size-bins, namely, the fine $(0.01-1.0 \mathrm{~m}$,), accumulation (1.0-2.5 m), coarse $(2.5-5.0 \mathrm{~m})$, and giant (5.0-20.0 m) particle-size modes (Zakey et al. 2006a, b). Using prognostic dust bin concentrations, long-wave refractive indices, and absorption cross sections, the dust particle long-wave emissivity/absorptivity influences are implemented based on (Solmon et al. 2008). The representation of dust emission processes is a key element in a dust model and depends on the wind conditions, soil characteristics, and particle size. Following previous methods in the literatures, the dust emission calculation is based on parameterizations of soil aggregate saltation and sandblasting processes. In relation to the BATS interface, these parameterizations become effective in the model for cells dominated by desert and semi desert land cover. At present, we do not account for sub-grid fractional desert cover, that is a grid point is considered to be either totally covered by desert or with no desert cover. Equation 1 is the dust parameterization equation in tracer's model as coupled in RegCM4; the equation comprises of transport term, primary emission term, removal term, and physico-chemical term:

$\frac{\partial X}{\partial t}=-\bar{V} \times \nabla x+F_{H}+F_{V}+T_{\mathrm{CUM}}+S_{z}-R-D_{\text {dep }}+\sum\left(Q_{p}-Q_{i}\right)$,

where $V$ is the specified velocity, $\nabla$ is the spatial gradient operator, $X$ is the Dust mixing ratio, $F_{H}$ is the horizontal turbulent diffusion, $F_{V}$ is the vertical turbulent diffusion, $S_{z}$ is the emission term, $D_{d e p}$ deposition flux, and $Q_{p}$ is the particle.

\section{Experimental design}

In this study, three experiments with RegCM4 Model were performed and presented. The model was integrated from October, 2004 to December, 2005. However, the simulation of October-December, 2004 was considered as spin up and discarded to allow for the model stability. The first experiment which is refer to as CONTROL with Biosphere-Atmosphere Transfer Scheme (BATS) of RegCM4 model and without aerosol interference were run, the second experiment also refers to as (DUST) case with coupled dust model and run concurrently, while the third experiment represents a case when the aerosol is double and thereafter refer to as (DOUBLE DUST) case study.

\section{Remote-sensing data sets}

\section{Multiangle Imaging Spectroradiometer (MISR)}

Multiangle Imaging Spectroradiometer (MISR) was launched by the National Aeronautics and Space Administration (NASA) on December 18, 1999 and has been in operation since February 2000. The device consists of nine push broom cameras arranged to view at nominal zenith angles relative to the surface reference ellipsoid of $0.0^{\circ}, \pm 26.1^{\circ}, \pm 45.6^{\circ}, 18 \pm 60.0^{\circ}$, and $\pm 70.5^{\circ}$ and measures upwelling short-wave radiance in each camera at four spectral bands, centered at 446, 558, 672, and $866 \mathrm{~nm}$ [142]. With high spatial resolution and a better radio metrical and geometrical accuracy, the multiple angle-band observations of MISR allow the retrieval of a number of aerosol optical and microphysical properties over land (including a bright desert surfaces) and ocean [36-38, 100, 143-145]. Furthermore, MISR-AOD retrievals (level-3 data) have a higher grid resolution $\left(0.5^{\circ} \times 0.5^{\circ}\right)$ in comparison to the Moderate Resolution Imaging Spectroradiometer (MODIS) of Level-3 which has the resolution of $1^{\circ} \times 1^{\circ}$. In the present study from MISR-level-3-monthly-averaged data sets (version 31, which are available from 2000 onward), the AOD at $558 \mathrm{~nm}$ are utilized to evaluate the simulated results. Multiangle Imaging Spectroradiometer provides radiometrically and geometrically calibrated images in four spectral bands at each of the angles. Spatial sampling of 275 and $1100 \mathrm{~m}$ is provided on a global basis with a temporal resolution of 16 days, but radiances at $1.1 \mathrm{~km}$ resolution are processed to yield the standard Level-2 MISR aerosol product at $17.6 \mathrm{~km} \times 17.6 \mathrm{~km}$ pixel size. Martonchik et al. (1998) created a heterogeneous land algorithm. These properties have proofed the uniqueness of MISR over other remote sensors. The MISR data information is available on https://www-misr.jpl.nasa.gov/.

\section{Sea-viewing Wide Field-of-view Sensor (SeaWiFS)}

Since September of 1997, SeaWiFS routinely provides ocean color and atmospheric products, e.g., the normalized water-leaving radiance $\left[L_{w}(\lambda)\right]_{N}$ for six visible wavelengths $(412,443,490,510,555$, and $670 \mathrm{~nm})$, chlorophyll-a concentration Chl- a, AOT at $865 \mathrm{~nm} \tau_{a}(865)$, and the aerosol Angström exponent derived from the wavelength 510 and $865 \mathrm{~nm} \alpha(510)$. SeaWiFS has gone through four major reprocessings of the entire data set. Each reprocessing has addressed the data quality issues that are related to the sensor calibration, instrument navigation, data masks and flags, and retrieval algorithms. The SeaWiFS data used in here are from the fourth data reprocessing which was carried out in July 2002 (Patt et al. 2003). Currently, the SeaWiFS data processing is optimized for the ocean color measurements (e.g., chlorophyll- a concentration). Very 
high AOT data such as the dust and smoke plumes are usually masked out due to large uncertainties in the ocean color products with these cases (Gordon 1997). The SeaWiFS has a reflectance threshold at $865 \mathrm{~nm}$ corresponding to the AOT of $\sim 0.3$. Thus, the current SeaWiFS aerosol products are mostly applicable and valid in the open ocean regions where the marine aerosols are often the dominant sources. It is noted that, however, the SeaWiFS measurements can be used to derive the aerosol optical properties for very thick aerosol layers, e.g., for the dust study (Husar et al. 2001; Moulin et al. 2001a), and possibly for the ocean color data in the regional case study (Moulin et al. 2001b). Implementation is planned for an aerosol retrieval scheme in which very high AOT (e.g., dust and smoke) can still be retrieved, even though the ocean color data may have large uncertainties. In these cases, flags can be applied to the ocean color products. The choice of SeaWiFS over other sensors is as a result of its capability to capture marine aerosols around the West Africa region and also serve as tool to validate the performance of RegCM4 in capturing Aerosol Optical depth which cut across heterogeneous surfaces.

\section{Moderate Resolution Imaging Spectroradiometer (MODIS)}

Moderate Resolution Imaging Spectroradiometer is a key instrument that is carried on both the Terra (EOS AM) and Aqua (EOS PM) satellites. Terra's orbit around the earth is timed, so that it passes from north to south across the equator in the morning, while Aqua passes south to north over the equator in the afternoon. The MODIS instrument has 36 spectral bands that provide abundant information on atmospheric, terrestrial, and oceanic environments. The instrument uses different methods for data retrieval over land (Kaufman et al. 1997) and over oceans (Tanre et al. 2001). To improve the accuracy and quality of retrieved data, the algorithms used for MODIS have been updated to make use of improved cloud-masking processes, aerosol models, and the surface reflectance database (Remer et al. 2005). The MODIS aerosol product observes the encompassing aerosol optical thickness over the oceans comprehensively and over the landmasses. Moreover, the size distribution is determined over the seas, and the type of aerosol is inferred over the land. The aerosol product incorporates the "dark blue" algorithm recently created to get aerosol optical thickness over bright land regions. The Dark Target algorithm is connected over sea and dark land (e.g., vegetation), while the Deep Blue algorithm in Collection (C6) covers the whole land regions including both dark and bright surfaces. Both results are provided on a $10 \times 10$ pixel scale $(10 \mathrm{~km}$ at nadir). The DB algorithm was constrained to just bright targets; however, it has extended inclusion to incorporate both bright targets and vegetated locales, utilizing NDVI information in addition to a precalculated surface reflectance database. The algorithm details on the information are available from https://modisatmos.gsfc.nasa.gov. For this study, the Terra Collection 006 Deep blue AOD data were used because of its prefer algorithm over land.

\section{Model input data sets}

\section{Era interim re-analysis data sets (EIN15)}

The first ECMWF Re-Analysis (ERA) project has produced a new, validated 15 year data set of assimilated data. Era-interim 15 (EIN15) is a grid data set with regcminput/ EIN15 as id. The data type is in netCDF dataformat. It has edu.ucar.unidata as naming authority and is freely available as NCEP model documentation. DOC/NOAA/NWS/ NCEP http://www.ncep.noaa.gov/creates EIN15 as regcm data input and also published by UCAR/UNIDATA http:// www.unidata.ucar.edu/. The data sets have Time step coverage. The project began in February 1993. The first phase of the work required the acquisition and preparation of the observations and forcing fields. During the 1st year, a substantial program of experimentation, closely co-ordinated with the Centre's Research and Operational activities, was completed. This enabled the scientific components of the reanalysis system to be defined, and a strategy for production to be determined. At the same time, work was progressing on the development of both the production system and the internal validation tools. The final production system was adopted in 1994, and there followed a period of sustained production, monitoring, and validation throughout 1995 and the first 9 months of 1996. All data generated by the project likely to be of future value have been collected and preserved. These include blacklist information, radiosonde bias correction tables, TOVS bias and calibration files, and the record of which satellites have been used at different periods.

\section{Results and discussion}

\section{JJAS seasonal Dust climatology in the West Africa region}

Mineral dust emission and transportation varies from season to season in the West Africa region with major source point at Bodele in the Republic of Chad and other sources across the Sahel. The Dust climatology over West Africa was described in Konare et al. (2008a, b) who found that RegCM3 adequately reproduces the mineral aerosol climatology of the region and the dust belt of the Sahel-Sahara region. Prospero et al. (2002) also discovered that West 
Africa has the highest rate of mineral dust emission especially at Bodele source point. It is also worth to note that the emission of mineral dust in the Sahel was as a result of characteristics of the desert surface, biomass burning, and other anthropogenic activities in the region, especially during the dry season. More importantly, the Bodele depression emits larger dust particles into the atmosphere. Wind played major roles in the transportation and dilution of the mineral dust in the atmosphere where coarse particles of the dust can be taken downwind. Different wind originates at different levels of the atmosphere and contributes largely in the distribution of aerosol. Figure 2 compares JJAS seasonal mineral dust AOD during the monsoon period in the West Africa region with RegCM4 and the dust AOD captured by the AERONET, MODIS, and SeaWiFS remote sensors. The RegCM4 captured the daily mineral dust AOD emission and deposition with the dust bands in the Sahel with average AOD value greater than 1.0 in the summer seasonal period between $16^{\circ} \mathrm{N}-20^{\circ} \mathrm{N}$ and $15^{\circ} \mathrm{W}-20^{\circ} \mathrm{E}$. The same dust characteristics also observed in the MISR and MODIS AOD pattern in the summer period of the year with the dust bands in the Sahel but with less magnitude. The reason for these differences is the dust parameterization in the RegCM4 which is responsible for high magnitude of dust replicated in the model. During summer season, however, there was less emission of mineral dust from the surface by low wind circulation, but there is high possibility of wet dust deposition during the boreal summer as a result of scavenging activity. Dust deposition is known as the measurement of amount of mineral dust that can be washed from the atmosphere and deposited at the surface in the region. Although mineral dust emission and transport is mostly occur in the winter than the summer, but the effect is seen on the precipitation amount. The disparity between the model results and that of MISR, SeaWIFs, and MODIS results is in the measuring algorithm that capture aerosol as an entity.

Figure 3 shows the time-series plot of annual dust Aerosol Optical Depth across the West Africa region with AERONET, MODIS-Terra, and SeaWiFS and RegCM4 data sets for five major AERONET stations in West Africa region including Agoufou in Mali, Bodele in the Republic of Chad, Banizoumbou in Niger Republic, Dakar in Senegal, and Ilorin in Nigeria. It was observed that all the selected remote sensors used measured higher dust AOD in DJF seasonal period in all the stations except for Bodele. The Bodele has the highest monthly distribution of dust AOD which is also replicated by RegCM4 model output. Figure $4 a$, b shows the region of annual and seasonal dust emission and distribution in the Planetary Boundary Layer of West Africa region. The Latitudinal region is found between $14^{\circ} \mathrm{N}-20^{\circ} \mathrm{N}$ and $15^{\circ} \mathrm{W}-20^{\circ} \mathrm{E}$ with an upward extension to about $700 \mathrm{hpa}$ which indicate the
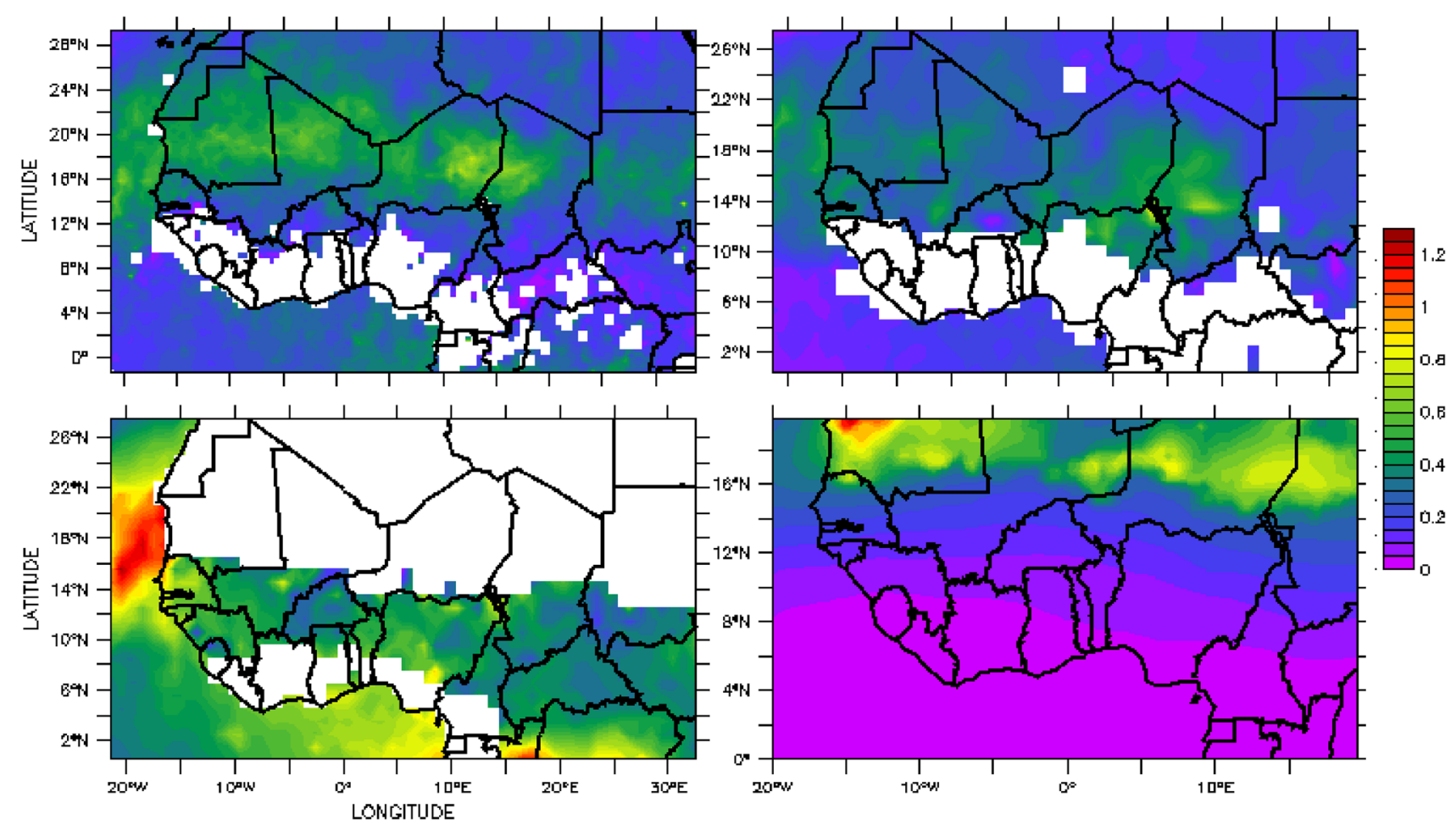

Fig. 2 JJAS Mineral Dust AOD emission and distribution in the West Africa Region: a MISR, b SeaWiFS, c MODIS, and d RegCM4 model 

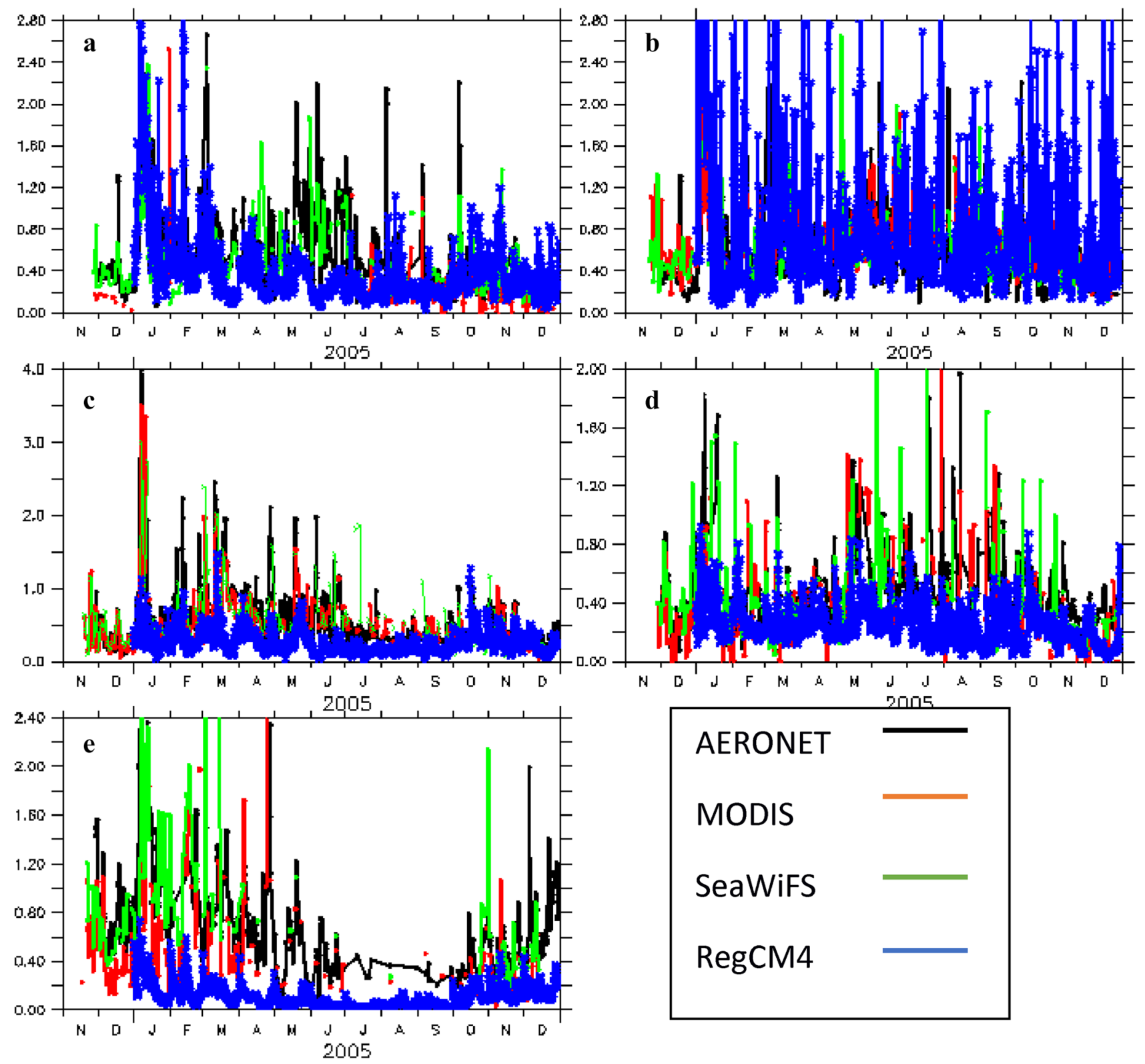

Fig. 3 Variation of Dust AOD with time for AERONET, MODIS-Terra, SeaWiFS and RegCM4 at a Agoufou, b Bodele, c Banizoumbou, d Dakar, and e Ilorin

Sahara Air Layer (SAL). A layer of air perturbation lies between 600 and 700 hpa level which is also responsible for dust mixing. It also aids westward transportation of dust from inland to the Atlantic Ocean, while Fig. 4c, d shows the seasonal emission and extent of vertical distribution of dust in the atmosphere at 500 hpa above the AEJ level.

\section{Response of Monsoon precipitation to mineral dust radiative forcing}

Monsoon is a period of inflow of moisture from the Atlantic Ocean to the inland of West Africa. The nature and variability of West Africa monsoon is being determined by evolving ocean, atmospheric constituents, and land conditions. Many studies have actually assessed the capability of RegCM in simulating precipitation climatology over West Africa region. For example, Sylla et al. (2012) assessed the capability of RegCM3 to reproduce the seasonal temperature and precipitation cycle during the period of 1981-2000 

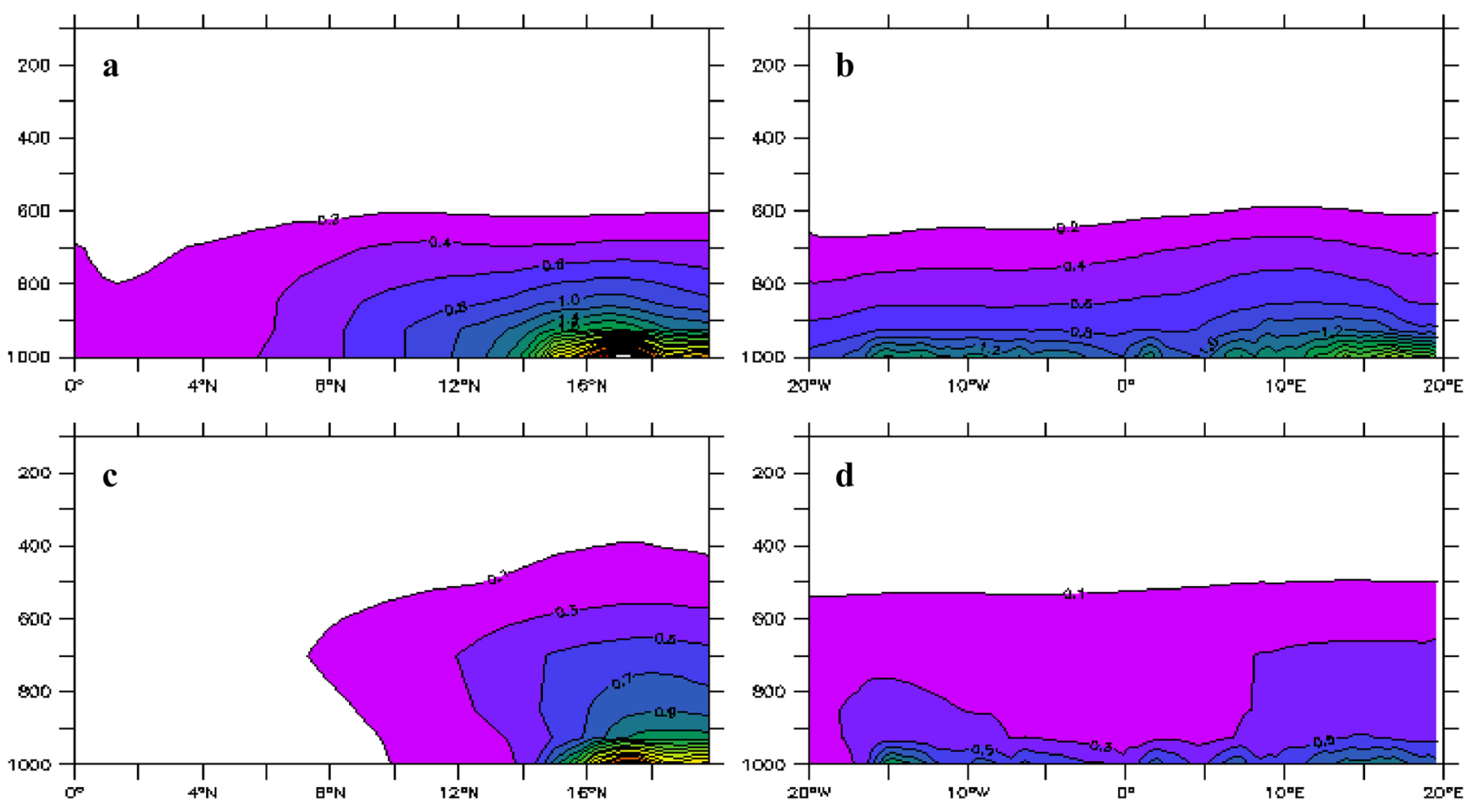

Fig. 4 Vertical extension of mineral dust in the Planetary Boundary Layer. a Annual latitude emission and transport of dust between 1000 and 700 hpa level. b Annual dust emission points along the longi-

tude of West Africa. c JJAS Latitude emission and transport of dust between 1000 and 400 hpa level with limited coverage areas. d JJAS dust emission points along the longitude of West Africa region

over West Africa with two sets of boundaries conditions, reanalysis data, and ECHAM5 output. These works were also in line with Solmon et al. (2008). The changes in precipitation could be linked to the fact that more short wave is being scattered in the atmosphere with higher dust concentration and this reduces the energy budget received at the surface.

Figure 5a shows the seasonal cycle of West Africa precipitation pattern including monsoon evolution in the Control experiment. The seasonal cycle of West African rainfall is characterized by a northward migration of the zonally oriented maximum from a southerly position during boreal winter to a northerly position in Early-to-mid August, followed by a more rapid retreat from September to November. The same figure also reveals the migration of precipitation and apparent latitudinal "jump" in the location of rainfall maximum at the end of June from the coastal region around $5^{\circ} \mathrm{N}$ to about $10^{\circ} \mathrm{N}$ (Sultan and Janicot 2003; Le Barbe et al. 2002). The monsoon jump, however, results into high rainfall amounts in the Sahel region of West Africa accompanied by abrupt reduction in precipitation intensities along the Guinean coast. In September, the rain band retreats southward towards the Guinea coast accompanied by a decrease in rainfall amount in the Sahel. Figure 5c shows the difference in precipitation between the double dust and the control experiment with reduction of precipitation in the annual circle. This is an

indication that increases in dust concentration increases radiative forcing which in turn reduces precipitation across the Sahel region.

Figure 6 shows the time-latitude plot for precipitation pattern in the West Africa region with monsoon jump around June and the peak in August-September, a period characterized with convective rainfall with thunderstorm while precipitation retreats in October. The Sahel rainfall pattern almost behaves alike with the Savannah but with reduction in precipitation amount. The peak of precipitation is found around September. In general, the Double Dust indicates increase in precipitation in some part of the region and the difference between the Double Dust and Control indicates reduction in precipitation in some other parts of the region.

\section{Response of temperature to the experiments}

Air temperature variation in the West Africa region is very important as it determines weather variability in the region. Figure $7 \mathrm{a}$ presents temperature variation in the Control experiment. In this case, Sahel region with maximum temperature value of $38.5^{\circ} \mathrm{C}$ was observed and this implies a very high-temperature values as a result of short-wave radiation attenuation at the top of atmosphere and less absorbance of long-wave radiation in the Sahel and this leads to prevalent warming in the Sahel than elsewhere in the region. 

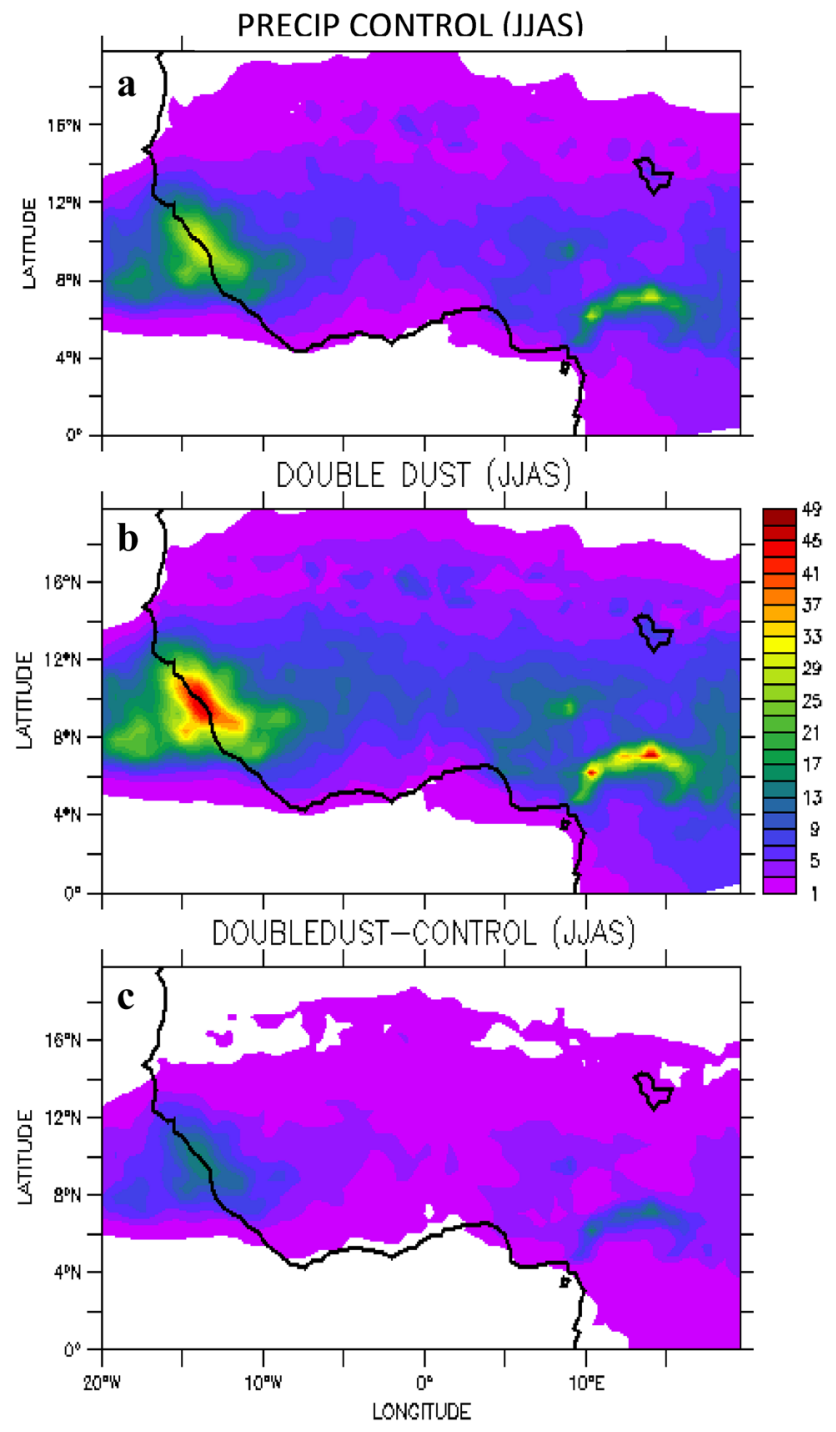

Fig. 5 Seasonal precipitation response to a Control, b Double Dust, and $\mathbf{c}$ Double Dust minus Control experiment

Figure $7 \mathrm{~b}$ also shows Double Dust case experiment which indicates increase in dust concentration leading to more scattering of short-wave and less absorbance of long-wave radiation and in turn leads to increase in temperature at the surface. The Sahel region recorded highest temperature values in the double dust experiment, while other areas including the Savannah and Guinea coast also experienced increase in temperature compare to Control experiment. Figure 7c shows the difference temperature values between the Double Dust and the Control experiment indicating cooling effects of temperature value of $12{ }^{\circ} \mathrm{C}$ in the Guinea coast as well and $18{ }^{\circ} \mathrm{C}$ in the Sahel. Underline surface characteristics is an important factor in the temperature cooling in the West Africa region which contributes to scattering and absorbing of dust in the region.
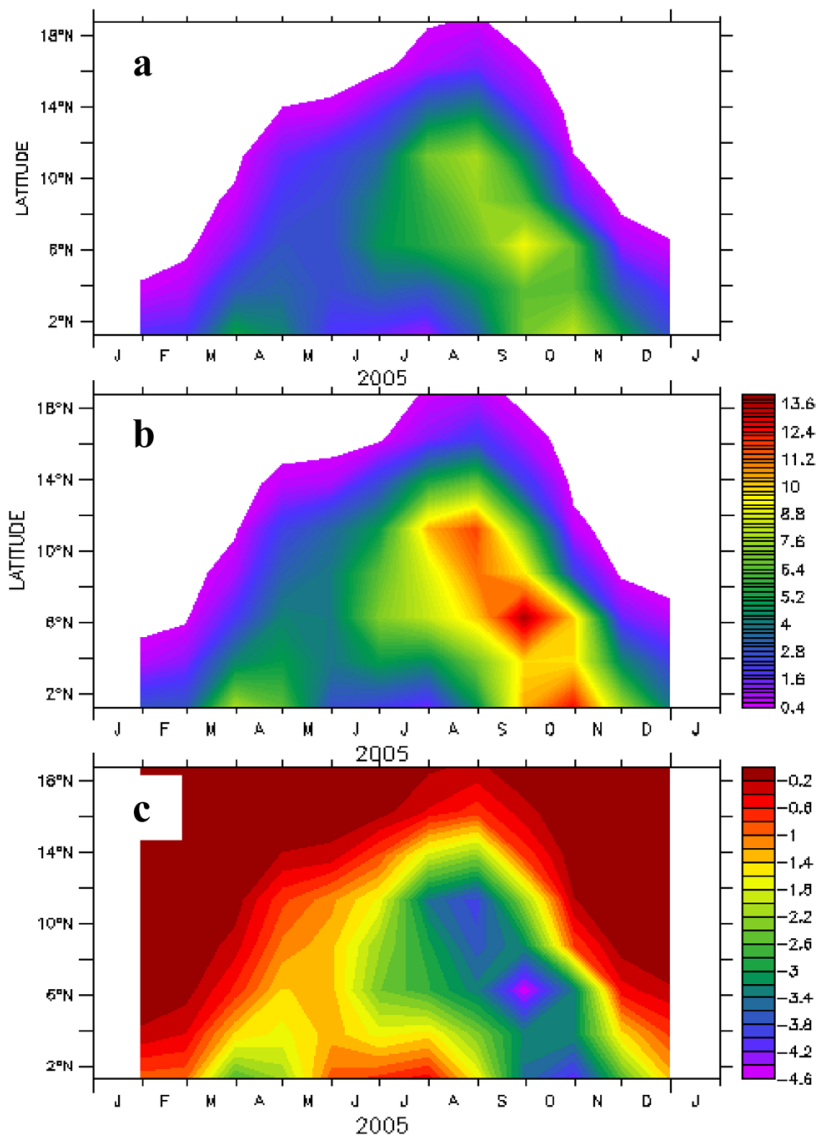

Fig. 6 Inter-annual precipitation response to a Control, b Double Dust, and $\mathbf{c}$ Double dust minus Control experiment

\section{Radiative forcing at the top of atmosphere}

Hypothetically mineral dust both scatter and absorb shortand long-wave radiation energy aloft and this refers to as direct radiation forcing of aerosol. Previous analysis shows the mineral dust bands with coarse particles in the Sahel. Smaller particles of aerosol are seen to be more prevalent in Sahel region, especially in Agoufou, Bodele, Banizoumbou, and Dakar with high single scattering albedo values. Figure 8 presents mineral dust short-wave radiation forcing at the top of atmosphere in JJAS seasonal climatology for Control, Double Dust case, and difference between the two case studies. There was short-wave radiation forcing of about -5 to $-9 \mathrm{~W} / \mathrm{m}^{2}$ over the dust band in the Sahel indicating high scattering potential of the dust in the region.

There was another important observation at the shore of Mali and Mauritania where there were extension of dust through transportation to the ocean and this increases the water surface albedo which is responsible for the high negative short-wave radiation forcing of about -13 to $-17 \mathrm{~W} /$ $\mathrm{m}^{2}$ on the Ocean. This has been observed by Miller et al. (2004), Zakey et al. (2006a, b). Time-series plot of Fig. 9 

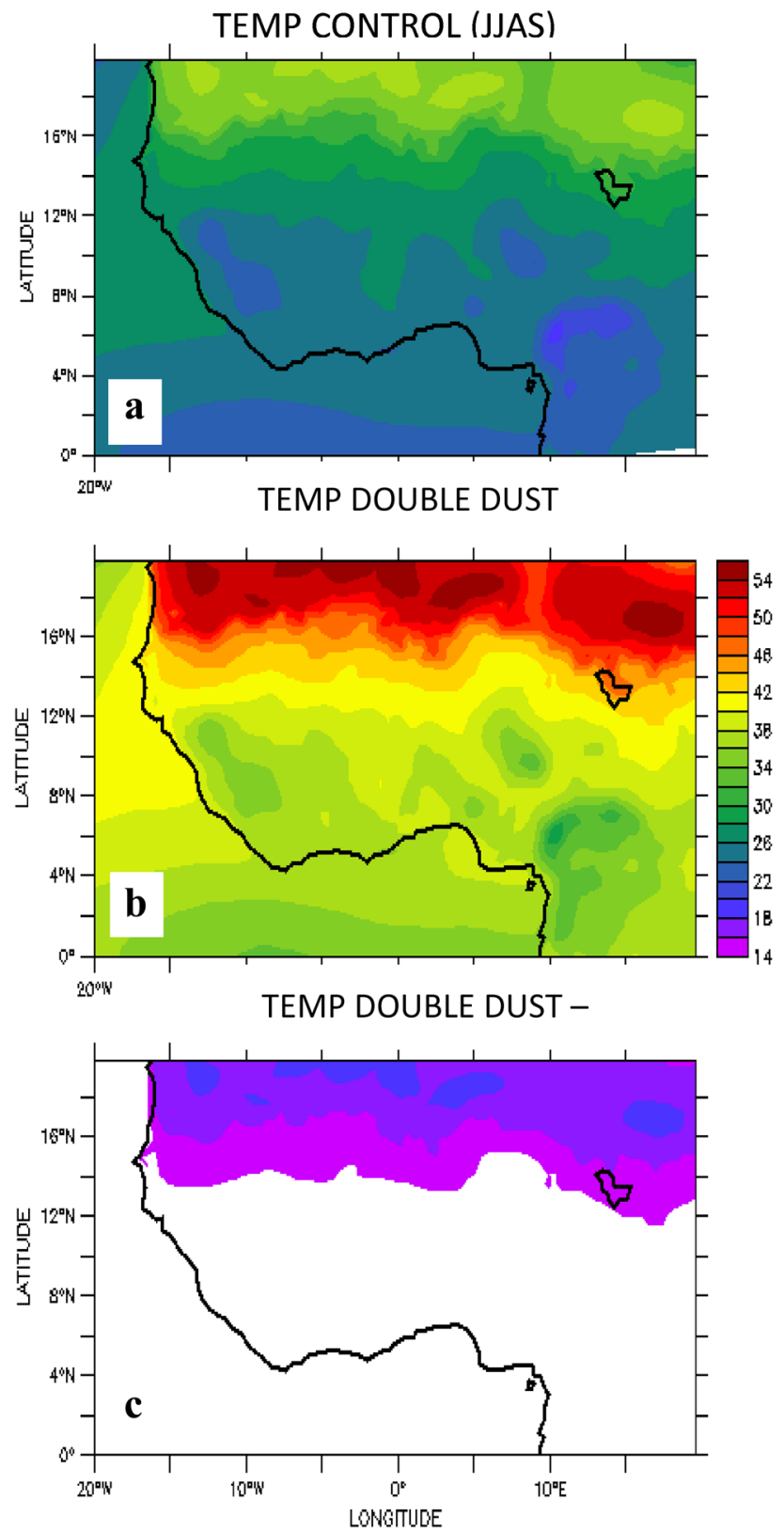

Fig. 7 JJAS mean daily temperature $\left({ }^{\circ} \mathrm{C}\right)$ for a Control, b Double Dust, and c Double Dust minus Control experiment

shows decrease in short-wave radiative forcing at the top of atmosphere from $-22 \mathrm{~W} / \mathrm{m}^{2}$ at the Guinea coast to $-60 \mathrm{~W} /$ $\mathrm{m}^{2}$ between 12 and $14^{\circ} \mathrm{N}$ in the Sahel for the dust case and decrease from -38 to $90 \mathrm{~W} / \mathrm{m}^{2}$ in the same latitude in the Double Dust case experiment.

Figure 10 shows short-wave radiative forcing at the surface across the entire West Africa region with an average values of $-28 \mathrm{~W} / \mathrm{m}^{2}$ around Bodele source point in the Control experiment. Increase in dust concentration induced short-wave radiative forcing of $-40 \mathrm{~W} / \mathrm{m}^{2}$ at the surface
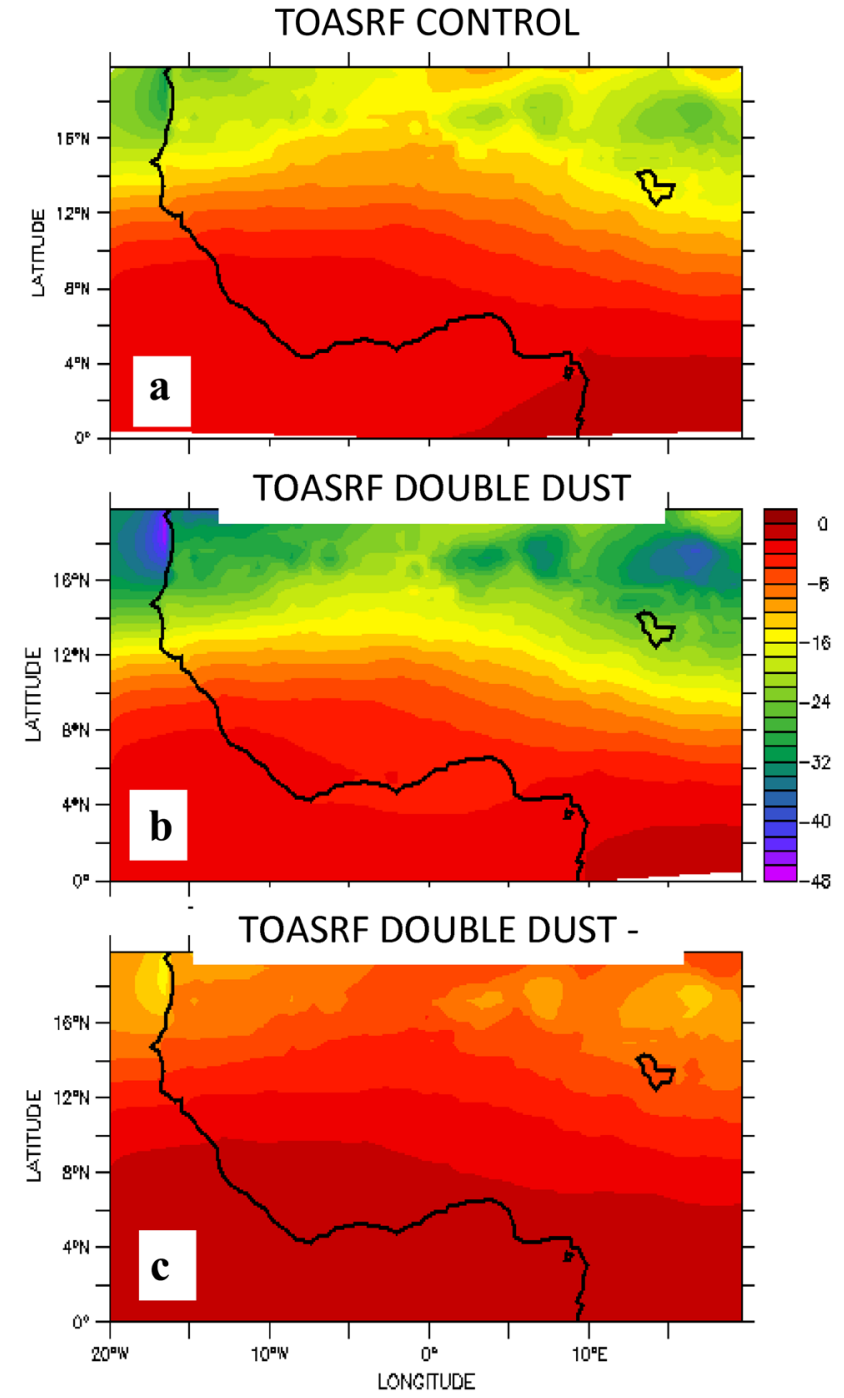

Fig. 8 Top of atmosphere short-wave radiative forcing for a Control, b Double Dust, and c Double dust minus Control experiment and Surface short-wave radiative forcing for a Control, b Double Dust, and $\mathbf{c}$ Double dust minus Control experiment

across the Sahara and Sahel dust belt with the highest values at the dust source regions at Bodele and Banizoumbou. The latitudinal pattern of the surface short-wave radiative forcing is with maximum value of $-180 \mathrm{~W} / \mathrm{m}^{2}$ between 16 and $18^{\circ} \mathrm{N}$ and from -50 to $-260 \mathrm{~W} / \mathrm{m}^{2}$ in the Control and Double Dust case study. The surface short-wave reduction in the region is an indication of surface cooling which is a result of dust concentration variability in the Sahel. Radiative forcing at the surface follows the spatial distribution of AOD in the region. This was also noted by Konare et al. $(2008 \mathrm{a}, \mathrm{b})$ and Solmon et al. (2008).

Figure 11 shows upward long-wave radiation flux in the West Africa region. The highest value of upward longwave radiation flux is found along the Sahel and the lowest 
Fig. 9 Latitudinal variation of radiation for a TOA short-wave radiation forcing and $\mathbf{b}$ surface short-wave radiation forcing
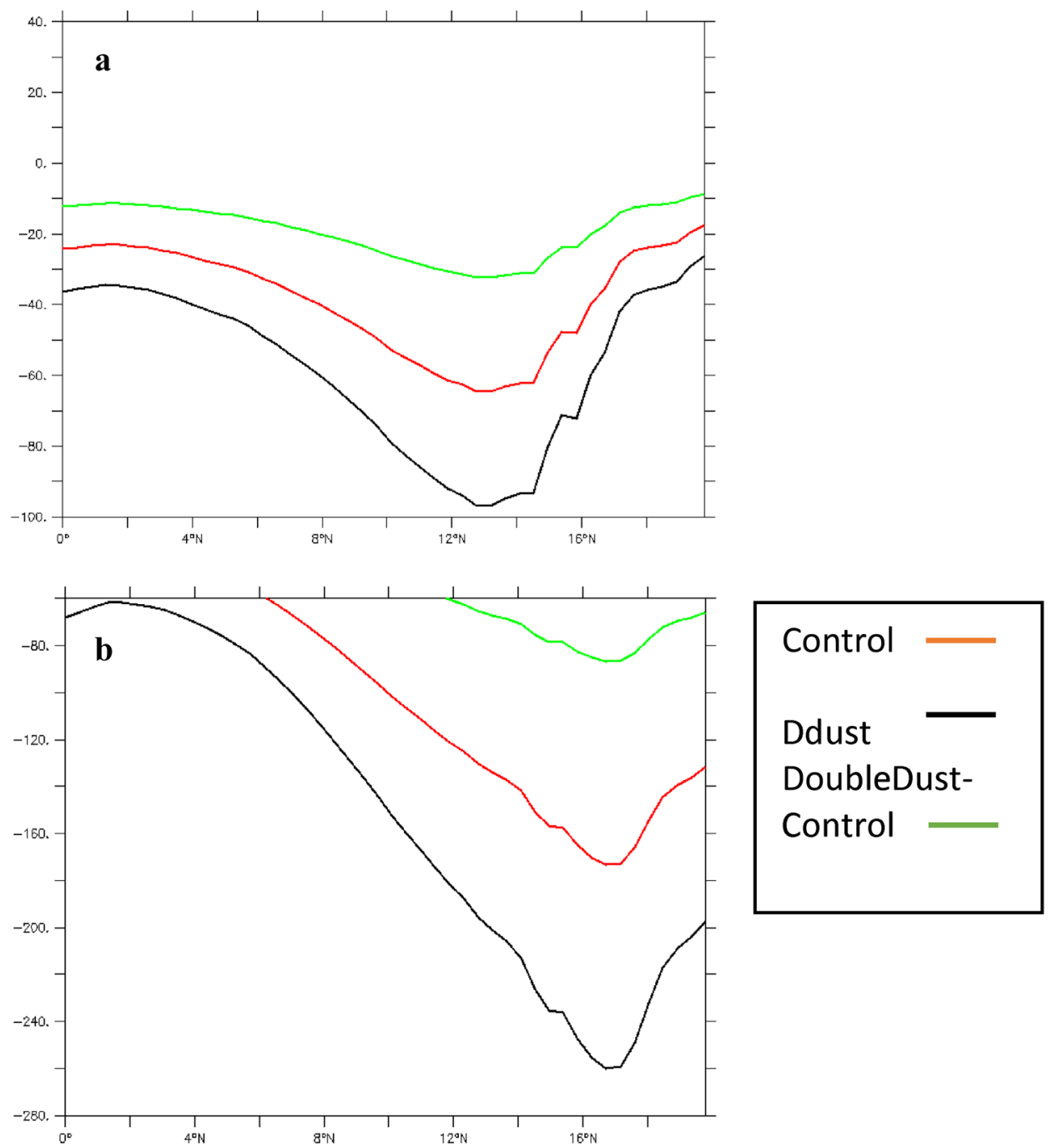

value at the Guinea coast in the Southern part of West Africa. As the dust concentration increases in the Double Dust experiment, there was increase in the upward long-wave radiation flux across the entire region, thereby reducing potential of cloud formation even in the Guinea coast. The difference between Double Dust and Control experiment shows decrease in upward long-wave radiation flux, but has larger coverage in the Guinea coast which enhances cloud formation potential in the region when compared to the control experiment.

\section{Zonal and surface wind response to the experiments}

The South-westerly trade and north-easterly trade wind are the two major trade winds over West Africa associated with wet and dry seasonal period. The prevalent of each trade wind determines the position of ITD in the region as it migrates North-Southward differentiating one trade wind from another.
Figure 12 shows zonal wind characteristics at different pressure levels. The Dust case (Fig. 10a) shows the monsoon wind core speed of $4 \mathrm{~m} / \mathrm{s}$ at the surface and the Africa Easterly Jet (AEJ) with core speed of $8 \mathrm{~m} / \mathrm{s}$ reflecting normal situation, since there is no significant difference between Control and Dust case experiment. In the same vein, the Tropical Easterly Jet (TEJ) with stronger core speed of $12 \mathrm{~m} / \mathrm{s}$ shows a very strong feature in the summer seasonal period. The double dust in Fig. 12b reflects increase in mineral dust concentration with a significant influence on the Jets characteristics. The monsoon is strengthened with $10 \mathrm{~m} / \mathrm{s}$ and the AEJ also increases by $18 \mathrm{~m} / \mathrm{s}$, while TEJ increases by $24 \mathrm{~m} / \mathrm{s}$, respectively. In the summer period, TEJ is strengthened, while AEJ weaken. These changes reflect radiative forcing of mineral dust as it induces changes in the two major jet streams and monsoon inflow over the region. The increase noticed in the zonal wind features is reflected in the enhancement of precipitation in the Guinea coast as a result of increase in mineral dust concentration which in turn increase SSA. The monthly variation of the zonal wind in the 

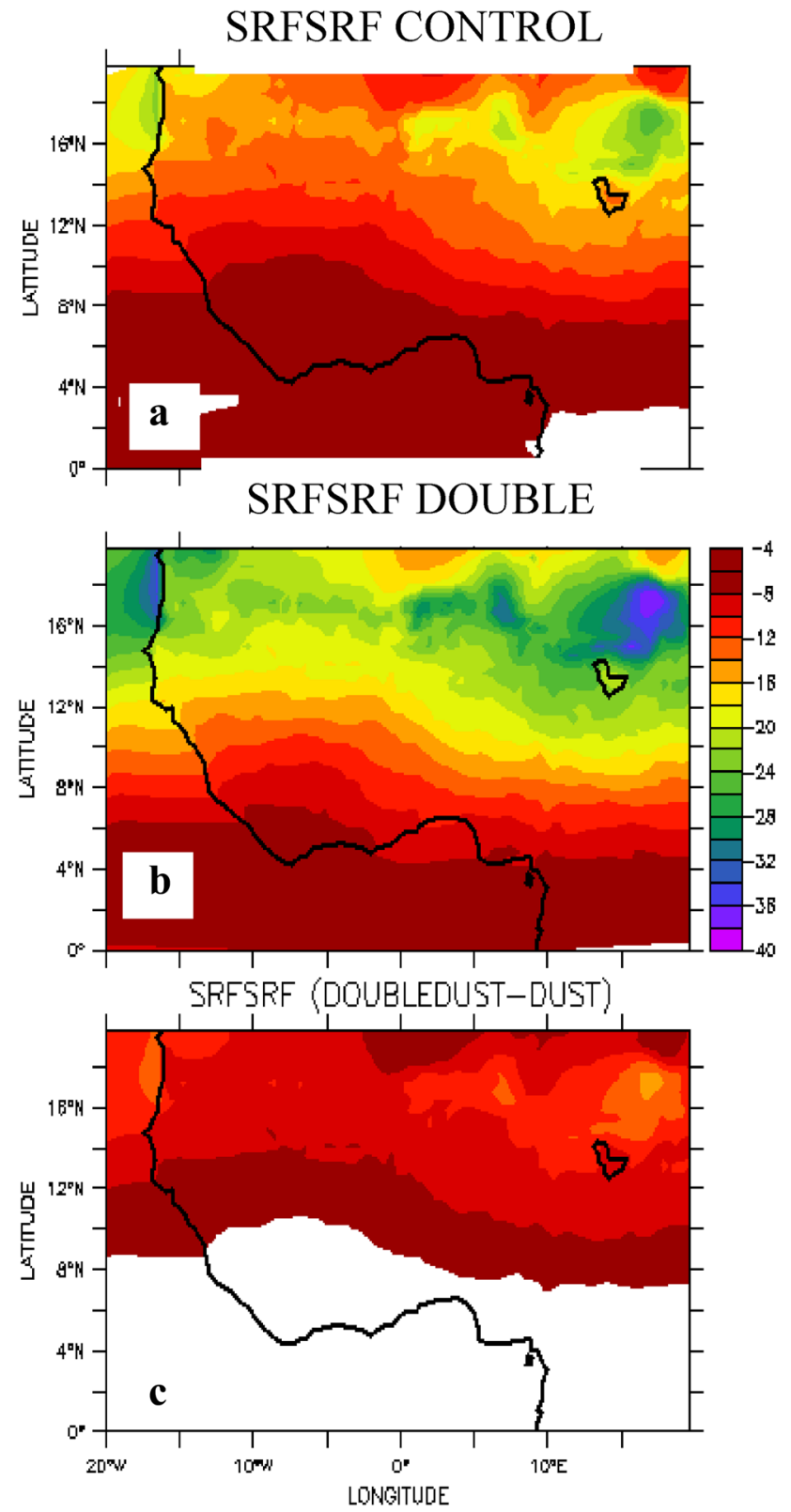

Fig. 10 Short-wave radiative forcing at the surface for a Control, b Double Dust, and c Double dust minus Control experiment

JJAS period is shown in Fig. 11. The first panel shows characteristics of the wind in June with Monsoon speed of $4 \mathrm{~m} / \mathrm{s}$ and $8 \mathrm{~m} / \mathrm{s}$ for Control and Double Dust case experiment. Monsoon is strengthened with speed of 6-12 m/s in August during Dustt and Double dust experiment indicating more inflow of moisture in August. Africa Easterly Jet core speed of $9.5 \mathrm{~m} / \mathrm{s}$ was also found in August except for TEJ which has its highest speed of $15 \mathrm{~m} / \mathrm{s}$ in July. Tropical Easterly Jet in general is strengthened, while AEJ is weakened in JJAS summer period. The same trend of zonal wind characteristics was recorded in Grist and Nicholson (2001).
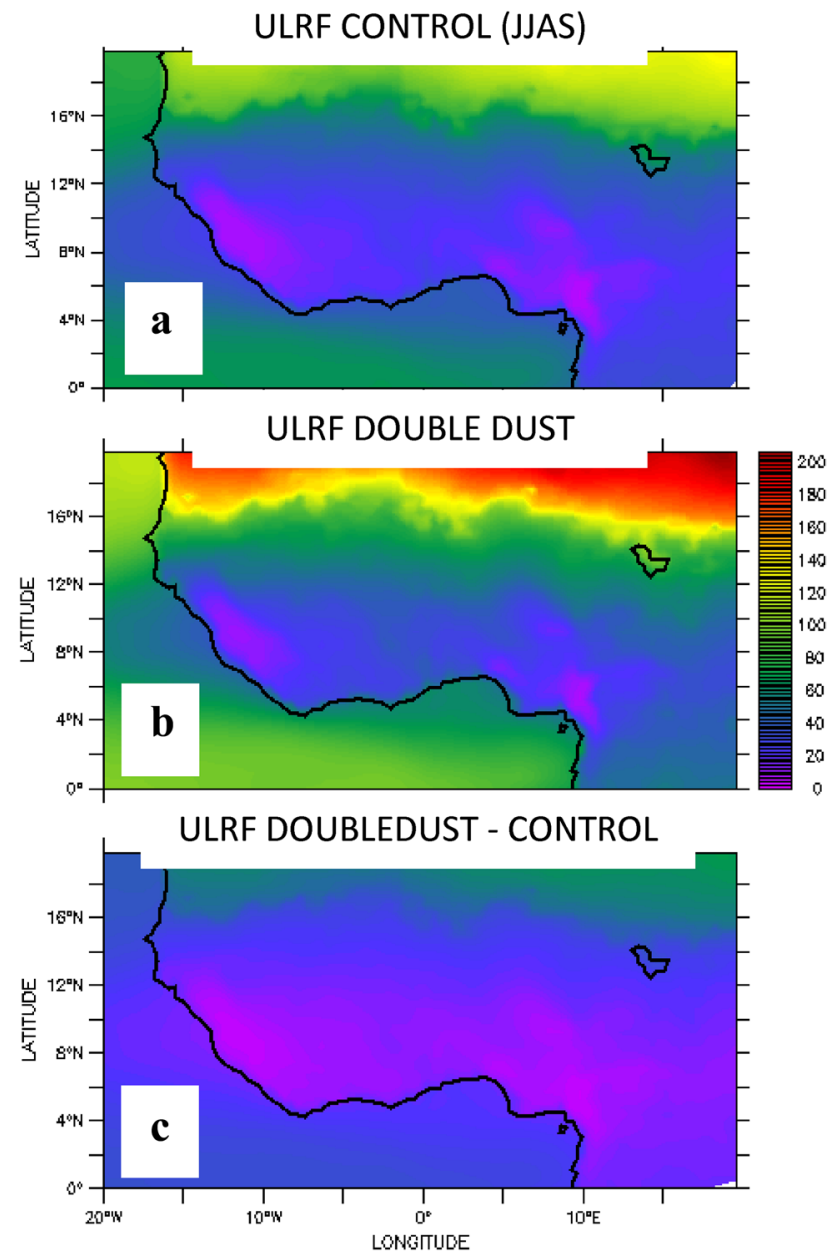

Fig. 11 JJAS net upward long-wave radiation flux for a Control, b Double dust, and $\mathbf{c}$ Double dust minus Dust

\section{Summary and conclusion}

In performing the sensitivity experiments, three mineral dust scenarios were used. The first scenario was Biosphere-Atmosphere-Transfer System, this is a scenario with no dust to serve as Control other aerosol radiative forcing considered includes the dust enabled scenario over West Africa to ascertain the areas that are feasible for dust emission and transport and the double dust scenario to observe the effects of increase in dust concentration on the dust Optical characteristics. There was an observation of an enhancement of monsoon precipitation in the double dust experiment. The increase in precipitation from 2 to $4 \mathrm{~mm} /$ day was mostly felt in the Guinea coast region and with minimal or no such increase elsewhere. The monsoon precipitation reduction noticed in the Sahel in the dust experiment was due to dust scattering ability, thereby reducing net radiation received at the surface which in turn reduces out going long-wave radiation which enhances cloud formation and another factor was the slight 

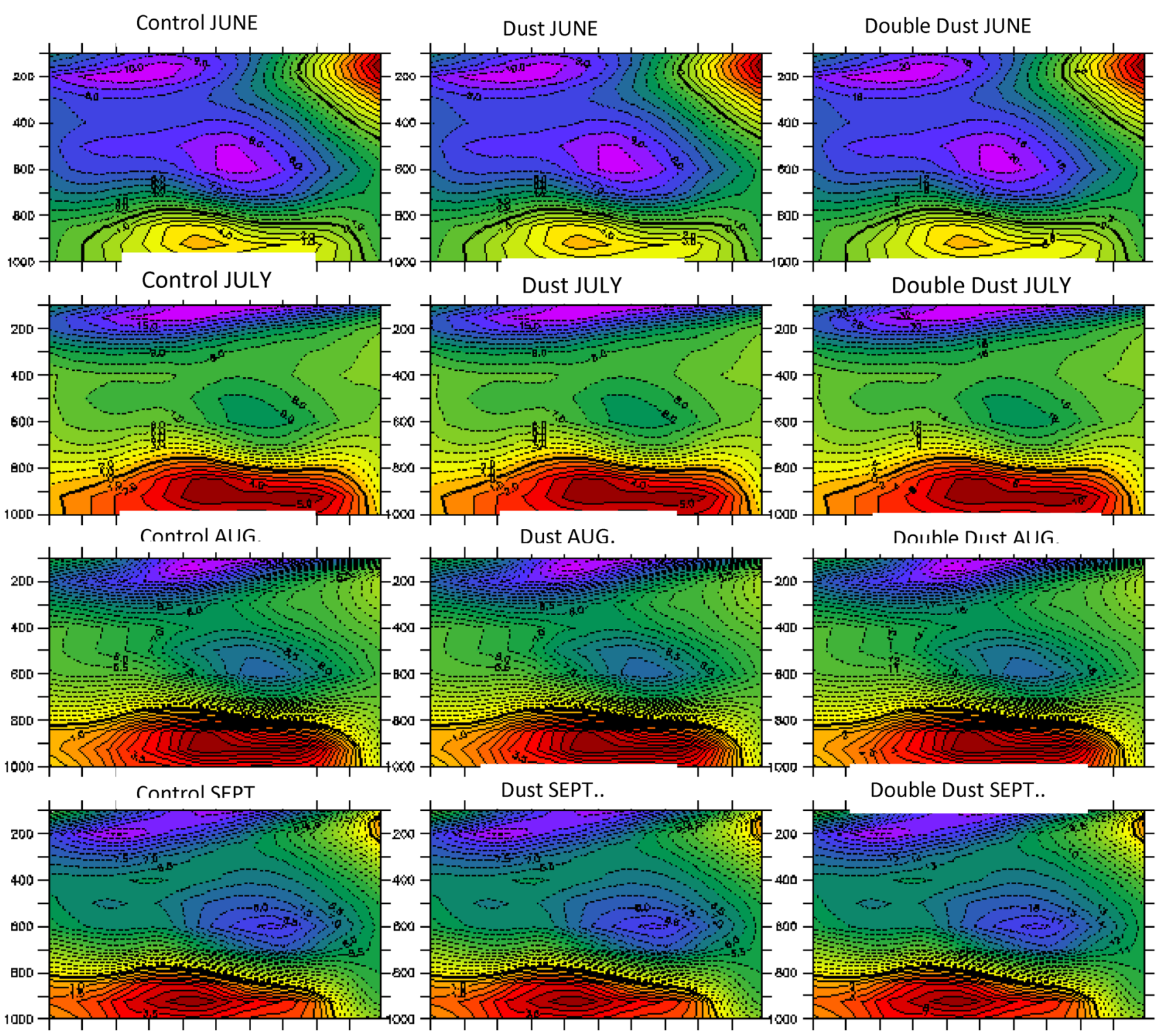

Fig. 12 Changes in Zonal wind and response to Control, Dust, and Double Dust experiment in (first panel) June, (second panel) July, (third panel) August, and (fourth panel) September

reduction in the speed of the AEJ. This reduction in the speed of AEJ combined with the slight reduction in the core speed of TEJ may have led to changes in the vertical wind shear between the two jets. At the Top of Atmosphere (TOA), there was negative radiative forcing noticed across the West Africa region, but with about $-15 \mathrm{~W} / \mathrm{m}^{2}$ in the Sahel region and as the dust concentration increases in the double dust experiment, there were high negative values of radiative forcing of aerosol in the region. This means that there was more scattering of short-wave radiation at the Top of Atmosphere as the dust concentration increases.

The study has clearly demonstrated the effect of mineral dust radiative forcing on the environment which alters radiation processes and climate feedback. It can also be observed that climate change issue is strongly related to atmospheric constituent change. The study also shows how increase in mineral dust concentration can enhance rainfall in the Guinea coast, but aid drought in the Sahel region. 
Reduction of anthropogenic activities that increase dust emission in region must be reduced to reduce the drought occurrence in Sahel region of West Africa. With further detail study, the experiment can serve as a feasibility study for field campaign experiment as a mitigation strategy of climate change in West Africa region.

Acknowledgements The authors sincerely appreciate International Centre for Theoretical Physics (ICTP), Italy for permission to use their model (RegCM4) for this work. The assistance of Graziano Gulaini is also greatly appreciated and every individual that have contributed immensely during the writing of the manuscript.

Open Access This article is distributed under the terms of the Creative Commons Attribution 4.0 International License (http://creativeco mmons.org/licenses/by/4.0/), which permits unrestricted use, distribution, and reproduction in any medium, provided you give appropriate credit to the original author(s) and the source, provide a link to the Creative Commons license, and indicate if changes were made.

\section{References}

Abiodun BJ, Adeyewa ZD, Oguntunde PG, Salami A, Ajayi VO (2012) Modeling the impacts of reforestation on future climate in West Africa. Theor Appl Climatol 110(1-2):77-96

Akinyoola JA, Eresanya EO, Orimoogunje OOI, Oladosu K (2018) Monitoring the spatio-temporal aerosol loading over Nigeria. Model Earth Syst Environ. https://doi.org/10.1007/s4080 8-018-0485-2

Andreae MO, Jones CD, Cox PM (2005) Strong present-day aerosol cooling implies a hot future. Nature 435:1187-1190

Camara M, Jenkins G, Konare A (2010) Impacts of dust on West African climate during 2005 and 2006. Atmos Chem Phys 10(2):3053-3086

Choobari OA, Zawar-Reza P, Sturman A (2014) The global distribution of mineral dust and its impacts on the climate system: a review. Atmos Res 138:152-165

Diedhiou A, Janicot S, Viltard A, De Felice P (1998) Evidence of two regimes of easterly waves over West Africa and tropical Atlantic. Geophys Res Lett 25:2805-2808

Eresanya EO, Oluleye A, Daramola MT (2017) The influence of rainfall and temperature on total column ozone over West Africa. Adv Res 10(2):1-11 (Article no. AIR.34312)

Fink AH, Engel T, Ermert V, van der Linden R, Schneidewind (2016) Mean climate and seasonal cycle (Chapter 1). In: Parker DJ, DiopKane M (eds) Meteorology of tropical West Africa: the forecasters' handbook. Wiley, Chichester

Fontaine B, Janicot S, Moron V (1995) Rainfall anomaly patterns and wind field signals over West Africa in August (1958-1989). J Climate 8:1503-5101

Fontaine B, Trazaska S, Janicot S (1998) Evolution of the relationship between near and global and Atlantic SST modes and the rainy season in West Africa: statistical analyses and sensitivity experiments. Clim Dyn 14:353-368

Giorgi F, Coppola E, Solmon F, Mariotti L, Sylla M, Bi X, Elguindi N, Diro GT, Nair V, Giuliani G, Cozzini S, Guettler I, O’Brien T, Tawfik A, Shalaby A, Zakey AS, Steiner A, Stordal F, Sloan L, Brankovic C (2012) RegCM4: model description and preliminary tests over multiple CORDEX domains. Clim Res. https://doi. org/10.3354/cr01018

Gordon HR (1997) Atmospheric correction of ocean color imagery in the Earth Observing System era. J Geophys Res 102:17081-17106
Goudie AS, Middleton NJ (2001) Saharan dust storms: nature and consequences. Earth Sci Rev 56(1-4):179-204

Grist JP, Nicholson SE (2001) A study of the dynamic factors influencing the variability of rainfall in the West African Sahel. Climate 14:1337-1359

Haywood JM, Boucher O (2000) Estimates of the direct and indirect radiative forcing due to tropospheric aerosols: a review. Rev Geophys 38(4):513-543

Haywood JM, Shine KP (1997) Multi-spectral calculations of the radiative forcing of tropospheric sulphate and soot aerosols using a column model. Q J R Meteorol Soc 123:1907-1930

Husar RB et al (2001) Asian dust events of April 1998. J Geophys Res 106:18317-18330

Kaufman YJ, Tanre D, Remer LA, Vermote EF, Chu A, Holben BN (1997) Operational remote sensing of tropospheric aerosol over land from EOS moderate resolution imaging spectroradiometer. J Geophys Res 102:17051

Kaufman YJ, Tanre D, Boucher O (2002) A satellite view of aerosols in the climate system. Nature 419:215-222

Konare A, Zakey AS, Solmon F, Giorgi F, Rauscher S, Ibrah S, Bi X (2008a) A regional climate modeling study of the effect of desert dust on the West African monsoon. J Geophys Res 113:D12206. https://doi.org/10.1029/2007JD009322

Konare A, Zakey AS, Solmon F, Giorgi F, Rauscher S, Ibrah S, Bi X (2008b) A regional climate modeling study of the effect of desert dust on the West African monsoon. J Geophys Res 113:D12206. https://doi.org/10.1029/2007jd009322

Le Barbe L, Lebel T, Tapsoba D (2002) Rainfall variability in West Africa during the years 1950-1990. J Clim 15:187-202

Levin Z, Ganor E (1996) The effects of desert particles on cloud and rain formation in the eastern Mediterranean. The impact of desert dust across the Mediterranean. Springer, Netherlands, pp 77-86

Liao H, Seinfeld J (1998) Radiative forcing by mineral dust aerosol: sensitivity to key variables. J Geophys Res 103(31):637-646

Marcella MP, Eltahir EA (2014a) The role of mineral aerosols in shaping the regional climate of West Africa. J Geophys Res Atmos 119(10):5806-5822

Marcella MP, Eltahir EA (2014b) The role of mineral aerosols in shaping the regional climate of West Africa. J Geophys Res Atmos 119(10):5806-5822

Marticorena B, Chatenet B, Rajot JL, Traoré S, Coulibaly MM, Diallo A, Koné II, Maman A, NDiaye T, Zakou AA (2010) Temporal variability of mineral dust content over West Africa: analyses of a pluriannual monitoring from the AMMA Sahelian Dust Transect. Atmos Chem Phys 10:8899-8915

Martonchik JV, Diner DJ, Kahn RA, Ackerman TP, Verstraete MM, Pinty B, Gordon HR (1998) Techniques for the retrieval of aerosol properties over land and ocean using multiangle imaging. Geosci Remote Sens IEEE Trans 36:1212-1227

Miller R, Tegen I (1998) Climate response to soil dust aerosols. J Clim 11(12):3247-3267

Miller RL, Perlwitz J, Tegen I (2004) Feedback upon dust emission by radiative forcing through the planetary boundary layer. J Geophys Res 109:D24209. https://doi.org/10.1029/2004JD004912

Ming Y, Ramaswamy V (2011) Amodel investigation of aerosolinduced changes in tropical circulation. J Clim 24(19):5125-5133

Moulin C, Gordon HR, Banzon VF, Evans RH (2001a) Assessment of Saharan dust absorption in the visible from SeaWiFS imagery. J Geophys Res 106:18239-18249

Moulin C, Gordon HR, Chomko RM, Banzon VF, Evans RH (2001b) Atmospheric correction of ocean color imagery through thick layers of Saharan dust. Geophys Res Lett 28:5-8

N'Datchoh ET, Diallo I, Konaré A, Silué S, Ogunjobi KO, Diedhiou A, Doumbia M (2018) Dust induced changes on theWest African summer monsoon features. Int J Climatol 38:452-466 
Nicholson SE, Grist JP (2001) A conceptual model for understanding rainfall variability in the West African Sahel on interannual and interdecadal timescales. Int J Climatol 21:1733-1757

Ogunjobi KO, Awoleye PO (2019) Intercomparison and Validation of Satellite and Ground-Based Aerosol Optical Depth (AOD) Retrievals over Six AERONET Sites in West Africa. Aerosol Sci Eng 3(1):32-47. https://doi.org/10.1007/s41810-019-00040-7 (ISSN 2510-375X)

Omotosho JB, Abiodun BJ (2007) A numerical study of moisture buildup and rainfall over West Africa. Meteorol Appl 14:209-225

Patt FS et al (2003) Algorithm updates for the fourth SeaWiFS data reprocessing, SeaWiFS Postlaunch Tech. Rep. Ser. In: Hooker SB, Firestone ER (eds) NASA Tech. Memo. 2003-206892, vol 22. NASA Goddard Space Flight Cent, Greenbelt, p 4

Prospero JM, Ginoux P, Torres O, Nicholson E, Gill TE (2002) Environmental characterization of global sources of atmospheric soil dust identified with the Nimbus 7 total ozone mapping spectrometer (TOMS) absorbing aerosol product. Rev Geophys 40(1):1002. https://doi.org/10.1029/2000RG000095

Remer LA, Kaufman YJ, Tanre D, Mattoo S, Chu DA, Martins JV, Li RR, Ichoku C, Levy RC, Kleidman RG, Eck TF, Vermote E, Holben BN (2005) The MODIS aerosol algorithm, products and validation. J Atmos Sci 62(4):947-973

Solmon F, Mallet M, Elguindi N, Giorgi F, Zakey A, Konaré A (2008) Dust aerosol impact on regional precipitation over western Africa, mechanisms and sensitivity to absorption properties. Geophys Res Lett 35(24):L24705. https://doi.org/10.1029/2008GL035900

Sultan B, Janicot S (2003) The West African monsoon dynamics. Part II: the "preonset" and "onset" of the summer monsoon. J Clim 16:3407-3427

Sylla MB, Gaye AT, Jenkins GS (2012) On the fine-scale topography regulating changes in atmospheric hydrological cycle and extreme rainfall over West Africa in a Regional Climate Model Projections. Int J Geophys 2012 (Article ID 981649)

Takemura T, Nozawa T, Emori S, Nakajima TY, Nakajima T (2005) Simulation of climate response to aerosol direct and indirect effects with aerosol transport-radiation model. J Geophys Res Atmos 110:D02202. https://doi.org/10.1029/2004JD005029

Tanre D, Kaufman YJ, Holben BN, Chatenet B, Karnieli A, Lavenu F, Blarel L, Dubovik O, Remer L, Sminov A (2001) Climatology of dust aerosol size distribution and optical properties derived from remotely sensed data in the solar spectrum. J Geophys Res 106:18205-18217

Titos G, Cazorla A, Zieger P, Andrews E, Lyamani H, GranadosMuñoz MJ, Olmo FJ, Alados-Arboledas L (2016) Effect of hygroscopic growth on the aerosol light-scattering coefficient: a review of measurements, techniques and error sources. Atmos Environ 1:1. https://doi.org/10.1016/j.atmosenv.2016.07.021

Wang G, Eltahir EAB (2000) Ecosystem dynamics and the Sahel drought. Geophys Res Lett 27(6):795-798

Zakey AS, Solmon F, Giorgi F (2006a) Implementation and testing of a desert dust module in a regional climate model. Atmos Chem Phys 6:4687-4704

Zakey AS, Solmon F, Giorgi F (2006b) Implementation and testing of a desert dust module in a regional climate model. Atmos Chem Phys 6:4687-4704

Publisher's Note Springer Nature remains neutral with regard to jurisdictional claims in published maps and institutional affiliations. 